\title{
Journeys to Crime: Assessing the Effects of a Light Rail Line on Crime in the Neighborhoods
}

Robin Liggett, Anastasia Loukaitou-Sideris, and Hiroyuki Iseki UCLA Department of Urban Planning

\begin{abstract}
The implementation of new transit lines is sometimes dogged by concerns that such lines may increase crime rates in station neighborhoods. Affluent communities have often complained that transit lines transport crime to the suburbs. This study focuses on the Green Line transit system in Los Angeles and examines its effects on crime in the adjacent areas. The Green Line light rail system passes through some high-crime, inner-city neighborhoods and terminates at its western end in affluent suburban communities. The study examines neighborhood level and municipalitywide crime trends for five years before and five years after the inception of the line. A piecewise regression model is developed to evaluate the impact of the opening of the line in the station neighborhoods. Geographic Information System (GIS) analysis is also utilized to identify spatial shifts in crime hot spots for the municipalities abutting the Green Line. The study finds little evidence that the transit line has had significant impacts on crime trends or crime dislocation in the station neighborhoods, nor has the line transported crime from the inner city to the suburbs.
\end{abstract}




\section{Introduction}

Does a transit line bring crime to the neighborhoods adjacent to its transit stops? Does a mass transit system that passes through crime-ridden inner-city areas help transport crime to the suburbs? Is such a line expanding the range of action of potential criminals by facilitating their "journeys to crime"? Such concerns have early on dogged the planning and implementation of light rail I ines in Los Angeles because of their alignment through areas vulnerable to crime.

Criminologists have called transit stations "crime attractors" and "fear generators" (Felson et al. 1990; Brantingham and Brantingham 1995) because they can generate crime and disorder by producing crowds. Urban railway stations have been described as behavior settings that gather flows of people on their way to work, shopping, or recreation. Some people are easy targets; being tired, preoccupied, carrying packages or other stealable objects (Myhre and Rosso 1996). But in addition to crime occurring at the station, some have argued that mass transit systems have the potential of "exporting" crime from one area to the other. According to Canadian criminologists Paul and Patricia Brantingham:

...transit shapes the crime pattern of the city by moving large proportions of high-risk populations around the city along a limited number of paths and depositing them at a limited number of destination nodes; awareness spaces and target search points become tightly clustered. Transit shapes the types of crime that are likely to be committed, by shaping the opportunity and the getaway potential of high-risk populations. (1991:93).

Some have also reported on the dual nature of the relationship between transit crime and the environment of adjacent neighborhoods, noting that the sociophysical characteristics of the immediate station area affect the danger at a transit station. At the same time, the presence of a station affects the danger in the immediate neighborhood (Block and Block 2000). In an earlier work, the Green Line transit system in Los Angeles was used to examine the first part of the "transit crime-environment" equation. The effects of socio-demographic and physical characteristics of station neighborhoods on crime incidence at the station were analyzed (Loukaitou-Sideris et al. 2002). This study showed that station crime was strongly related to ridership. Less serious crime (e.g., vandalism) was higher in stations located in dense neighborhoods with higher proportions of youth. Such crime tended to occur more in unkempt neighborhoods with deteri orating building stocks. Certain design characteristics of the station were related to platform 
crime against people. At the same time some socio-demographic indicators of the neighborhood (income, household size, concentration of youth) were also related to station crime. Finally, certain land uses in the transit neighborhood (notably the presence of liquor stores) were strongly correlated with station crime.

The present study focuses on the examination of the effects of the Green Line on its adjacent areas. Particular interest is placed on investigat ing possible crime influences of this inner-city line on its outlying suburban areas. More specifically, the study will respond to the following questions:

1. Have the neighborhoods adjacent to Green Line stations experi enced more crime after the introduction of the line?

2. Has the introduction of the line contributed to a shift or a dislocation of crime within the municipality?

3. Is there a concentration of hot spots of crime in areas adjacent to the station? Are these hot spots correlated with particular land uses?

4. Has the introduction of this line that passes through high-crime, innercity areas brought more crime to the outlying affluent suburban communities located at its western segment?

This article begins by outlining the theoretical background of the study by summarizing criminological theories that seek to explain a perpetrator's journey to crime and move through city spaces. This is followed by a literature review of empirical studies that have investigated the crime effect of transit systems on neighborhoods. Finally, the findings of our empirical research are presented and responses are provided to the aforementioned questions.

\section{Urban Structure, Mobility, and Crime}

A study of crime that involves an investigation of possible transit influences on surrounding areas requires examination of the concept of "journey to crime," the trip that an offender takes to access potential crimes (Plano 1993). Criminal justice theory has sought to trace the relationship between a criminal's mobility and the incidence of crime. As early as the 1930s, ecological theorists described movements through space as related to opportunity structures; arguing that criminals tend to move and act in city zones where more opportunities for crime are evident (Lind 1930; White 1932). Decades later Boggs (1966) simila rly suggested that environmental opportunities, which vary throughout an urban are a, determine 
crime rates. In a well-known article of the 1970s, Capone and Nichols argued that "criminal mobility is related to urban structure and the analysis of movement behavior will yield insight into offender decision-making and s patial preferences and contribute significantly to our understanding of the urban system as a crime opportunity structure" (1976: 200).

In the last decades, criminologists have become increasingly in terested in the spatial distribution of crime, as well as the journeys of criminals to commit crimes. Picturing criminals as rational decision-makers, they have noted, "... from a criminological perspective, if a person is searching for a target to rob, and several potential targets exist, all things being equal, the closest target will be chosen. All things are never equal, but it is argued that on the whole, there is a strong spatial bias that results in more short trips than long trips within any particular category of time" (Brantingham and Brantingham 1984:237). Theoretical work on the geometry of crime has assumed that the range of criminal activity for offen ders is determined by a "constricted awareness space" that is based on their familiarity with particular places (home, work, school, mall, park, etc.), and from areas a djacent to the paths that lead them to these sites (Brantingham and Brantingham 1991).

Empirical studies have shown that criminals can often travel beyond their immediate neighborhood to commit property crimes (robbery, burglary, car theft) (Capone and Nichols 1976; Pyle 1976). Capone and Nichols (1976) distinguished between "open space occurrences" and crime occurrences at "fixed premises," arguing that the former tend to be more spontaneous and not involving long travel, while the latter tend to require advance planning and o ften longer journeys to crime. However, differentiation exists between fixed premises, with liquor stores, supermarkets, and cash checking establishments requiring length ier trips, while residences, grocery stores, and gas stations exhibiting shorter average journeys to crime. Capone and Nichols concluded: "Urban structure and criminal mobility are inextricably linked, for criminal movement behavior is the product of an essentially rational structure of decision-making process that involves evaluation of an objective urban opportunity structure, the differential attractiveness of particular elements of that structure, and the universal constraint of dis tance (1976:211).

While there is a consensus that criminals may be willing to tra vel a certain distance to reach potential targets, some criminologists have also promoted the "distance decay theory." This argues that criminal travel patterns are characterized by a distance-decay function - the further the distance of a place from a criminal's place of residence (or point of origin) it is less likely that this criminal will travel to that 
place to commit a property crime. This is attributed to the fact that potential offenders do not have a good reconnaissance of distant areas (P lano 1993). Pyle (1976) studying crimes committed in 27 public housing estates in Cleveland found that for crimes against persons, the average distance between the offender's origin and destination was just under 2 miles. For property crimes, the average travel distance was 2.3 miles (Pyle 1976). Similarly, examining the di stribution of robbery incidents in Miami, Capone and Nichols (1976) found that the fr equency of robbery trips declined with increasing distance from the residential location of offenders. While findings from these studies seem to support the distance-decay function, this theory has been recently denounced by Van Koppen and Keijser (1997). According to them, studies showing a distance of decay of journeys to crime rely on correlations in aggregate data that cannot be good predictors of correlations in individual criminal behavior.

Regardless of whether the journey to crime is influenced by a consideration of distance, it is well known that other factors also intervene to enhance or decrease the appeal of a potential site as a target. These include the type of existing land uses, ${ }^{1}$ level of police and natural surveillance, environmental factors (visibility, lighting, urban form condition, etc.), area accessibility, ${ }^{2}$ and perceived opportunities for escape.

\section{Literature Review}

The criminological theories outlined in the previous section seem to give support to the notion that transit lines can expand a criminal's range of action. For one, rapid transit systems can compress the amount of time necessary for a criminal to reach his or her destination, and can familiarize him or her with an increased number of outlying areas. Second, the imposition of a major transportation artery, such as a transit line or a freeway, in an area increases the area's accessibility. In describing the "geometry of crime" Paul and Patricia Brantingham (1981) have argued that a concentration of criminal activities occur close to major transportation arteries and highways. Such contentions have supported the notion that transit lines might bring increased crime to the areas they serve, and have often fueled a neighborhood's reaction against the "intrusion" of a railway line, especially in more wealthy, suburban areas (Poister 1996). A study of resident and business perceptions prior to the initiation of construction activities for a MARTA station in Atlanta found that crime (after construction) was the second most major concern of residents, after traffic congestion (Ross and Stein 1985). 
While theory and public perception seem to agree that new transit lines have the potential to bring more crime to the surrounding neighborhoods, empirical research on the subject is quite mixed. Very few studies have analyzed the effect of railway stations on surrounding areas. In examining the environ s of Chicago railway stations, Block and Davis (1996) found that the bulk of rob beries were not concentrated immediately at the station, but about 1 to $1 \frac{1}{2}$ blocks away. Block and Block (2000) found the same pattern in Bronx, where 50 perc ent of all street robberies had occurred within about 700 feet of a transit stati on. The researchers argued that the high level of guardianship at the stations nega ted the great number and good choice of potential targets. Instead crime was dis placed in the near vicinity.

Little empirical research has investigated the issue of transit -related crime in outlying residential or commercial areas by perpetrators who have used the transit system. The findings of such studies are contradictory. In a study that analyzed police crime reports for transit-related crime in an unnamed city, Shellow et al. (1974) found that criminal predators tended to work in territories familiar to them and were not likely to use public transit as a means for extending their territory or as a means for escape. Examining crime patterns of the neighborhoods around three Baltimore stations for three years before an $d$ three years after the metro line's opening Plano (1993) found that reported crime was on an upward and erratic trend after the opening of the stations. However, lack of accurate crime locations prevented him from attributing the crime increases to the stations' openings, or from identifying any distance trends or clu stering patterns of the crime occurrences. An analysis of burglary trends before an $d$ after the opening of two MARTA stations in suburban Atlanta found no evidence to suggest that burglaries have increased after the opening of the stations (Po ister 1996). In a study of crime patterns before and after the opening of the Blu e Line in Los Angeles Loukaitou-Sideris and Banerjee (2000) found that in most station areas the introduction of the light rail line has reduced crime incidence in the immediate station neighborhood. The study also found that the station are a was relatively safer than its larger surrounding communities, a fact attributed to the high deployment and visibility of transit police.

The review of the literature reveals that the empirical research about the effect of transit on the crime rates of adjacent neighborhoods is quite inconclusive. The few studies on the topic have produced mixed or contradictory results. 


\section{The Context}

The Los Angeles Green Line is used as a case study in this rese arch to explore the impact of a transit line on crime in its adjacent neighborhoods. The researchers test the validity of the assumption that a transit line can transport crime from high-crime, inner-city areas to low-crime, suburban neighborhoods.

The Green Line is a light rail line that runs a total of $19.6 \mathrm{~m}$ iles from Norwalk (to the east) to El Segundo (to the west) in Los Angeles County (see map in Figure 1). The line has 14 stations and had a daily average ridership of 23,00 0 passengers in 2000. For the most part (16.3 miles), the line operates in the middle of the I-105 Freeway. As it nears El Segundo the line leaves its alignment in the fre eway median and continues for another 3.3 miles to its western terminus in Redo ndo Beach. Four suburban stations are located along this segment, all on elevat ed structures.

The Green Line corridor passes though communities that are quit e different. The 14 station-neighborhoods vary significantly in terms of their land uses and sociodemographic characteristics. The suburban neighborhoods at the western end of the line are more affluent than the inner-city neighborhoods in the middle. Neighborhoods at the eastern end can be characterized as middle clas s. In terms of racial characteristics, the western neighborhoods are primarily white, the inner-city neighborhoods are primarily Latino and African American, while the eastern neighborhoods are more diverse ethnically. Some stations are within primarily residential areas (although the ratio of single and multifamily housin $g$ varies). Some stations are surrounded by industrial facilities, some by primaril y commercial uses, while others have a mixture of uses in their vicinity.

Crime rates in the jurisdictions ${ }^{3}$ along the Green Line corridor also vary significantly (AEGIS 1991) (see Table 1). At its middle section the line has stations in high-crime, inner-city areas (e.g., Vermont, Harbor, Avalon, Wilmington, and Long Beach Blvd. stations). At its eastern edge the Green Line cross es communities with generally low to average crime rates (cities of Downey and Norwalk). At its western edge the Green Line runs through (or comes very close to) the low-crime suburban beach communities of El Segundo, Manhattan Beach, and Redon do Beach. The fact that the line passes through both high-crime, inner-city areas and lowcrime, suburban areas makes it a good case to test the validity of the perception that rapid transit brings crime to the suburbs. 


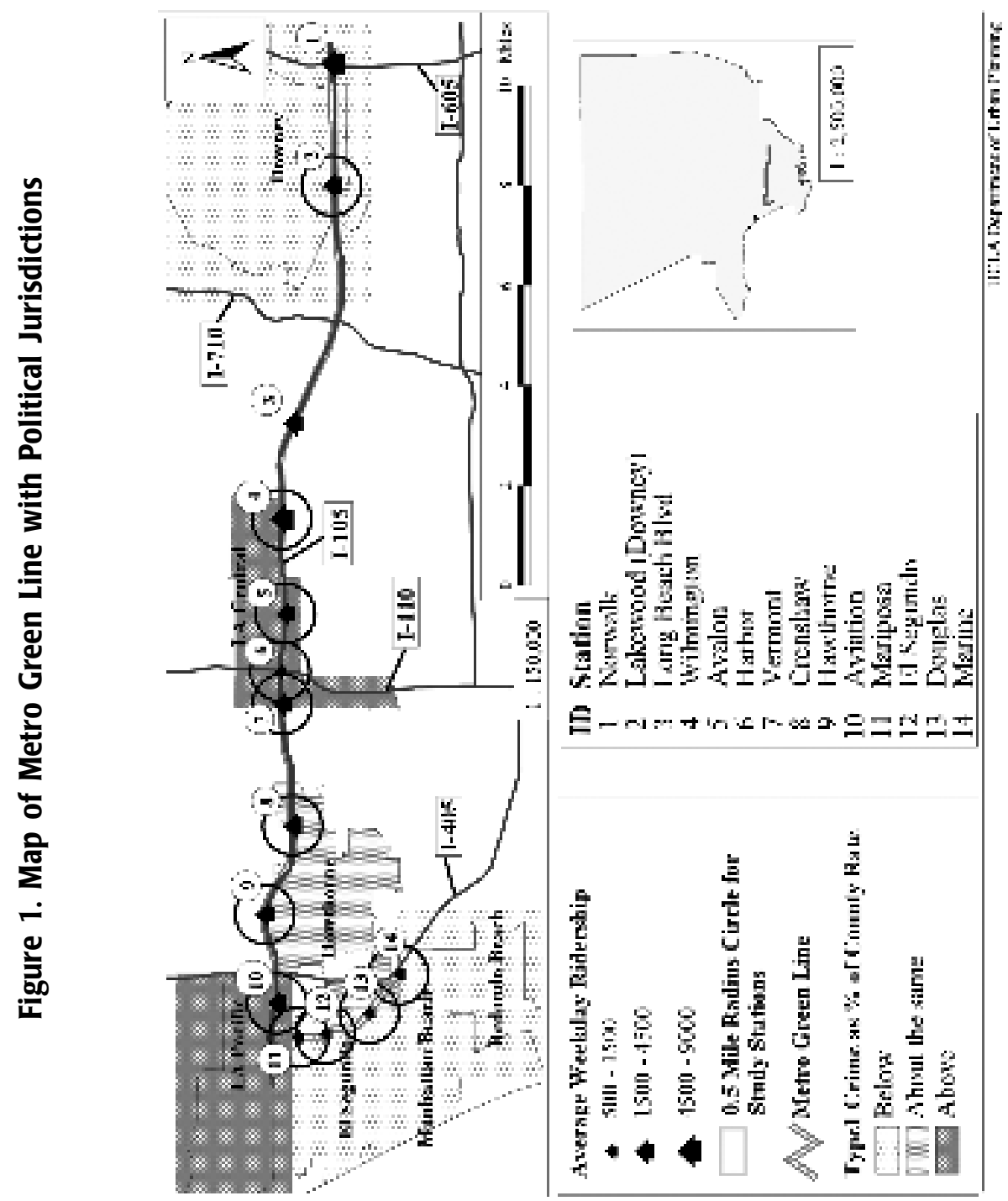


Table 1. Jurisdiction Crimes Rates*

\begin{tabular}{|l|c|c|}
\hline \multicolumn{1}{|c|}{$\begin{array}{c}\text { City/LAPD } \\
\text { Service Area }\end{array}$} & Stations & $\begin{array}{c}\text { Type 1 Crime as } \\
\text { \% of County Rate }\end{array}$ \\
\hline Downey & 2 & $72.1 \%$ \\
LAPD'Southeast & $4,5,6,7$ & $165.2 \%$ \\
Hawthorne & 8,9 & $116.4 \%$ \\
LAPD'Pacific & 10 & $148.3 \%$ \\
El Segundo & 11,12 & $87.5 \%$ \\
Manhattan Beach & 13 & $78.0 \%$ \\
Redondo Beach & 14 & $81.2 \%$ \\
\hline
\end{tabular}

*Green Line Security Analysis, April, 1991

\section{Research Design}

Crime data was collected for six cities adjacent to the Green Line and surrounding 12 of the 14 stations (data could not be obtained for areas adjacent to the Lynwood station \#3 and the Norwalk station \#1). Crime data by type ${ }^{4}$ and location for 1990 through 1999 was obtained from the cities of Downey, Los Angeles (LAPD service areas in the vicinity of the station), Hawthorne, El Segundo, $M$ anhattan Beach and Redondo Beach. Data was geocoded and aggregated to the station neighborhood level ( $1 / 2$ mile radius around each station) to generate a quarterly time series database for the 10-year period. ${ }^{5}$ To identify long-term trends, the crime series data sets were first adjusted for quarterly (seasonal) variation and then smoothed using three-month moving averages (Smith 1991; Poister 1996). S imilarly crime trend data was created for the larger municipalities/LAPD service areas abutting the Green Line over the 10-year period. This allowed us to study crime trend changes by quarter during the 10 -year period both at the station neighborhood level and larger municipality level. To control for other factors influencing crime rates, ${ }^{6}$ station neighborhood trends were also compared to county crime trends during the same period. Additionally, the geocoded crime data was used for GIS analysis, which attempted to identify spatial shifts in crime hot spots for the municipalities abutting the Green Line.

The study of the Green Line entails a methodological problem, since, for the most part, the line runs in the middle of the I-105 Freeway, which could also theoretically increase the accessibility of likely offenders to outlying suburban areas. To separate the crime effects of each station on the adjacent neig hborhoods, the level of crime in the areas around the Green Line stations was examin ed during three 
different time intervals: (1) January 1991 to September 1993 ( $p$ rior to the opening of the I-105 Freeway); (2) from October 1993 to August 1995 (wh en the Green Line started operation); and (3) from September 1995 to December 1999.

Additional data collected for our earlier study (Loukaitou-Side ris et al. 2002) provided information on socio-economic characteristics of the population in the station neighborhood as well as the primary land uses in the neighborhoods. We also had data from the Los Angeles Metropolitan Transit Authority (MTA) on boardings and alightings (ridership) by station (Table 2 ).

\section{Table 2. Station Neighborhood Characteristics}

\begin{tabular}{|c|c|c|c|c|c|}
\hline \multirow{2}{*}{ Station } & \multirow{2}{*}{ Ridership } & \multicolumn{4}{|c|}{$\begin{array}{c}\text { Neighborhood Characteristics } \\
\text { (1/2 mile radius) } \\
\end{array}$} \\
\hline & & Primary Land Use & Population & $\begin{array}{l}\% \text { Low } \\
\text { Income }\end{array}$ & $\begin{array}{l}\text { KOwner } \\
\text { Oceupied }\end{array}$ \\
\hline 2 & 2085 & Residenta & 5836 & $21 \%$ & $80 \%$ \\
\hline 4 & 8383 & Multi-family Residentis, Retail & 7425 & $58 \%$ & $29 \%$ \\
\hline 5 & 1696 & Residentiel & 6884 & $54 \%$ & $45 \%$ \\
\hline$B$ & 1326 & Residential, Retail & 6868 & $45 \%$ & $41 \%$ \\
\hline 7 & 2373 & Residentia, Retail & 8223 & $42 \%$ & $34 \%$ \\
\hline B & 2392 & Residentiel, Industrial & 2408 & $20 \%$ & $58 \%$ \\
\hline$\theta$ & 2285 & Residentid, Retail & 11363 & $40 \%$ & $24 \%$ \\
\hline 10 & 2748 & Vacent, Parking, Industrial, Omice & 705 & $12 \%$ & $72 \%$ \\
\hline 11 & 1358 & Industria, Office, Vecant, Parking & 21 & n/a & $\mathrm{Na}$ \\
\hline 12 & 1084 & Industrial, Office, Parking & 20 & $n / a$ & $\mathrm{na}$ \\
\hline 13 & 691 & Office, Retail, Industrial & 1706 & $9 \%$ & $84 \%$ \\
\hline 14 & 1064 & Otflce, Retail, Industrial & 1680 & $15 \%$ & $42 \%$ \\
\hline
\end{tabular}

\section{Crime Trend Analysis}

Nonauto related serious crime (Type 1) against persons began decreasing in Los Angeles County from a peak of about 145,000 crimes per quarter at the end of 1991 to a low of under 80,000 crimes per quarter by the end of 1999 (Figure 2). Type 1 crime related to autos also declined over the same time period. Starting at the end of 1991, the number of crimes decreased from a peak of about 35,000 in 1991 to a low of about 12,000 in 1999.

Most areas surrounding the Green Line stations experienced similar declining trends in Type 1 crime. Figure 3, for example, shows decreasing numbers of Type 1 nonauto crime in the station neighborhoods in the LAPD/Central jurisdiction. The present analysis focused on whether crime trends in the station neighbor- 


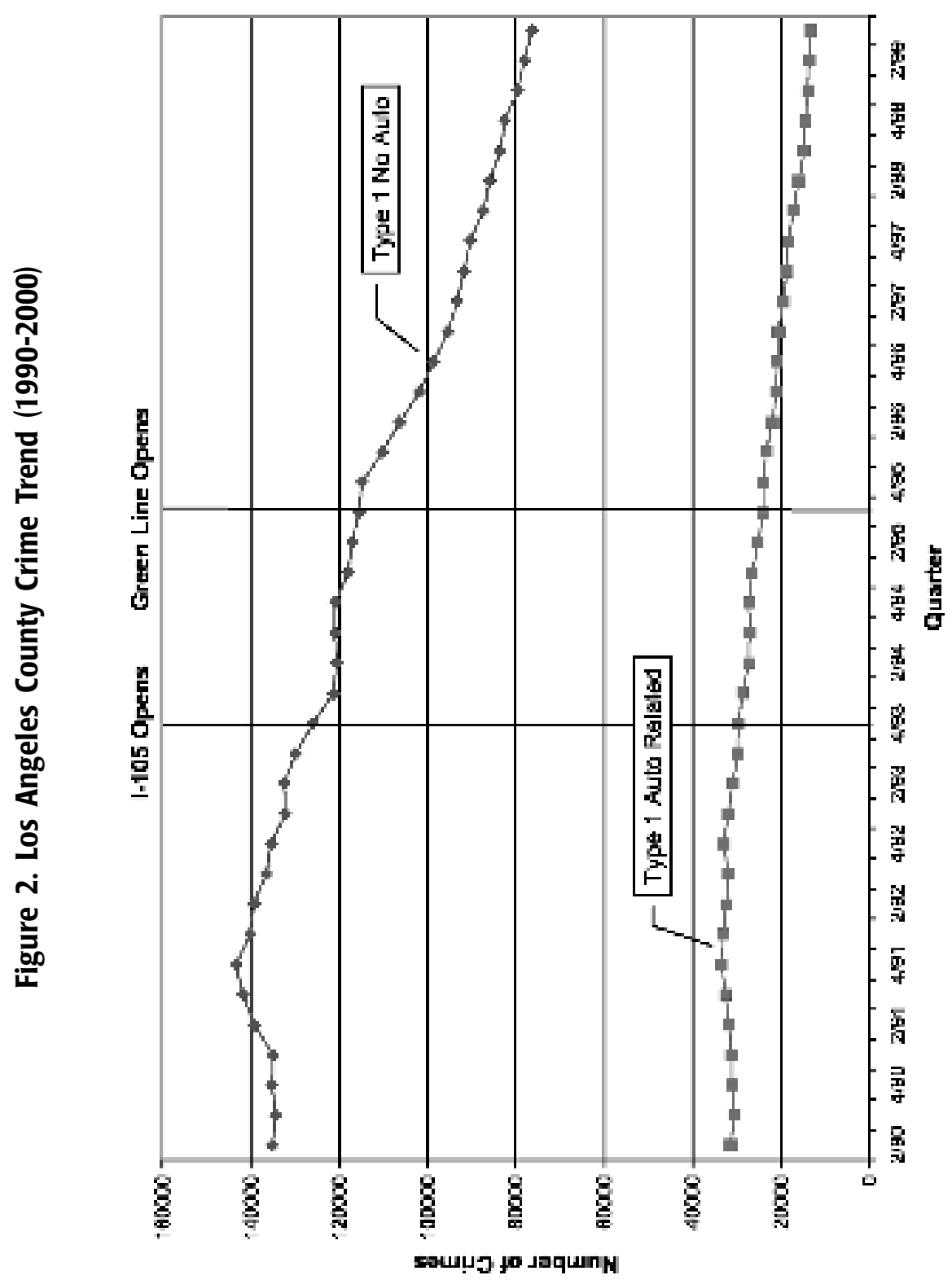


hoods (operationalized as $1 / 2$-mile radius surrounding the station) differed significantly from trends in the larger jurisdictions along the Green Line and/or the county as a whole. Was there an increase in crime after the fre eway or Green Line opened? Or, in the case of a decrease in station neighborhood crime, was the decrease less than what would be expected based on larger area trends?

To evaluate the impact of both the opening of the I-105 Freeway and the opening of the Green Line (shown by reference lines on the trend graphs) on crime in the station neighborhoods, the following piecewise regression model was developed for each station: ${ }^{7}$

Total crimes $=\mathrm{b}_{0}+\mathrm{b}_{1}{ }^{*}$ Time $+\mathrm{b}_{2}{ }^{*}$ FWOPEN $+\mathrm{b}_{3}{ }^{*}$ GLOPEN $+\mathrm{b}_{4}{ }_{4}^{*}$ IPOSTFW + $\mathrm{b}_{5}{ }^{*}$ IPOSTGL $+\mathrm{b}_{6}^{*}$ CONTROL

where:

Total crimes equals number of Type 1 No Auto, Type 1 Auto, or Type 2 crimes in the station neighborhood seasonally adjusted and smoothed

Time represents quarter ( $2^{\text {nd }}$ quarter 1990 is time 0 )

FWOPEN is the dummy variable for opening of Century Freeway:

$=0$, before $4^{\text {th }}$ quarter $1993($ Time $<14)$

$=1,4^{\text {th }}$ quarter 1993 and after (Time $>=14$ )

GLOPEN is the dummy variable for opening of Green Line:

$=0$, before $3^{\text {rd }}$ quarter 1995 (Time $\left.<21\right)$

$=1,3^{\text {rd }}$ quarter 1995 and after (Time $\left.>=21\right)$

IPOSTFW equals (Time-14)*FWOPEN (Measures change in slope after free way opens)

IPOSTGL equals (Time-21)*GLOPEN (Measures change in slope after Green Line opens)

CONTROL is the total crime at local city/jurisdiction level or at LA Co unty level used to control for other factors influencing crime rate trends. 


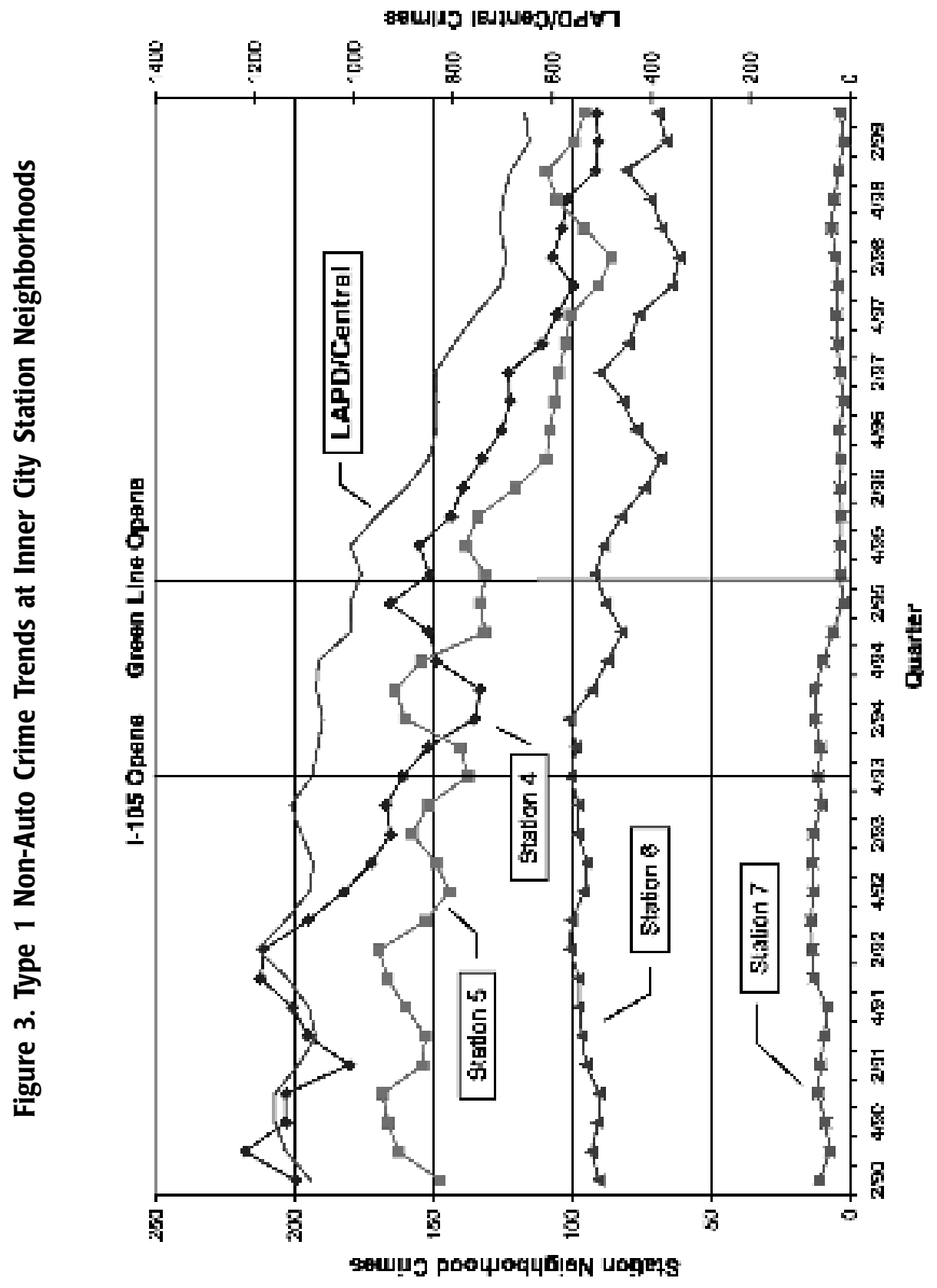


Tables 3 and 4 show results of fitting the piece-wise regression model to crimetime series data for each of the station neighborhoods. In the Table 3 models, crime trends at the local jurisdiction/city level are used for control while Los Angeles County crime trends are used as control in Table $4 .{ }^{8}$ Significant changes in slope and intercept post-freeway and post-Green Line are indicated wi th a "+" or "-" in the corresponding table cell, and positive changes (increases in crime) following the opening of the Green Line are further highlighted with shad ing.

\section{Table 3. Regression Model Results}

\begin{tabular}{|c|c|c|c|c|c|c|}
\hline \multirow{3}{*}{ Station } & \multicolumn{4}{|c|}{ Typn 1 Crims } & \multirow{2}{*}{\multicolumn{2}{|c|}{ Type 2 Crims }} \\
\hline & \multicolumn{2}{|c|}{ Non Nirto Rolabed } & \multicolumn{2}{|c|}{ Auito Falsind } & & \\
\hline & Post Fwy & Post GL & Poot Fwy & Poft GL & Post Fwy & Pont GL \\
\hline 2-Lakewood IDowney? & $\operatorname{con} 2=-2$ & + & 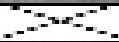 & & $=2=$ & + \\
\hline 4.WIImington & + & & + & $\bar{*}$ & & \\
\hline 5-Analon & & & & & & \\
\hline B-Hartaer & - & + & & & - & + \\
\hline 7.Vermant & - & + & & & + & - \\
\hline B.Crenshre & & + & & & & + \\
\hline B.Hawthorne & & & . & & + & \\
\hline 10-Avintiun & - & + & & & & \\
\hline 11-Murlposz & & & 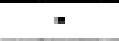 & + & & \\
\hline 12-El sogundo & & & & & - & \\
\hline 13-Dauglus ('A日) & & & & & & \\
\hline 14-Warine (Redondo) & - & - & 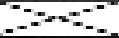 & - & & - \\
\hline
\end{tabular}

b) Change in Intercept Controlling for Local Jurisdiction Crime Trend

\begin{tabular}{|c|c|c|c|c|c|c|}
\hline \multirow{3}{*}{ stbion } & \multicolumn{4}{|c|}{ Type 7 Crims } & \multirow{2}{*}{\multicolumn{2}{|c|}{ Type 2 Crims }} \\
\hline & \multicolumn{2}{|c|}{ Non Asto Rolated } & \multicolumn{2}{|c|}{ Auto ficloted } & & \\
\hline & Pasal Fwy & Past GL & Pasil Fay & Pasal QL & Pual Fwy & Paul GL \\
\hline \multicolumn{7}{|l|}{ 2.Labswood |Downey } \\
\hline \multirow{2}{*}{\multicolumn{7}{|c|}{$\begin{array}{l}\text { 4. Wilmington } \\
\text { 5.Avalon }\end{array}$}} \\
\hline & & & & & & \\
\hline 6-Hartor & & & $=$ & + & & \\
\hline Y-Vermant & & & & - & & \\
\hline \multicolumn{7}{|l|}{ E.Cranghum } \\
\hline 9.Howtherne & - & - & + & & & - \\
\hline 10-Avistion & & & & & & $=$ \\
\hline \multirow{2}{*}{\multicolumn{7}{|c|}{$\begin{array}{l}\text { 11-Naripusa } \\
\text { 12-El Esgundo }\end{array}$}} \\
\hline & & & & & & \\
\hline \multicolumn{7}{|l|}{ 13-Douglas (AB) } \\
\hline 14-Marine ('Recbondu! & & & & - & & \\
\hline
\end{tabular}

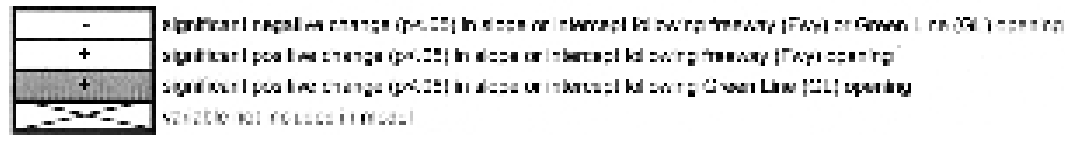




\section{Table 4. Regression Model Results}

\section{a. Change In Slope Controlling for County Crime Trend}

\begin{tabular}{|c|c|c|c|c|}
\hline \multirow{3}{*}{ Senfion } & \multicolumn{4}{|c|}{ Jype 1 Crfme } \\
\hline & \multicolumn{2}{|c|}{ Hor Auba Refalod } & \multicolumn{2}{|c|}{ Aufo Redrited } \\
\hline & Payf Fwy & PoplaL & Pow Fwy & Fos CII \\
\hline 2t-akewood (Downay) & & + & & . \\
\hline 4.wlimingban & + & & + & - \\
\hline 5-Auralen & & & & \\
\hline$\theta$ Hartor & $=$ & + & & \\
\hline J-Vermint & - & + & $\bullet$ & \\
\hline B-Grominth & $=$ & & & + \\
\hline g+Hawthorne & & & & + \\
\hline 10-Autatan & - & & - & + \\
\hline 11 Mariperes & + & & 4 & \\
\hline 12-EI Segundo & & & & \\
\hline 13-Douglas (М日) & & & & + \\
\hline 14-Marina (Redande] & & - & & - \\
\hline
\end{tabular}

b. Change In Intercept Controlling for County Crime Trond

\begin{tabular}{|c|c|c|c|c|}
\hline \multirow{3}{*}{ Staffian } & \multicolumn{4}{|c|}{ Type 1 Crime } \\
\hline & \multicolumn{2}{|c|}{ Horr Auto Ralitiod } & \multicolumn{2}{|c|}{ Asfo Reloted } \\
\hline & Pant fwy & Pnat QL & Past Puy & Past all \\
\hline 2-Lakmood (Downay) & $=$ & + & & \\
\hline \multicolumn{5}{|l|}{ 4-Wilmington } \\
\hline \multicolumn{5}{|l|}{ Edturalon } \\
\hline GHartar & & & & + \\
\hline T-Wermont & & & + & - \\
\hline \multicolumn{5}{|l|}{ B-Ginampipt } \\
\hline BHawthome & & - & & \\
\hline \multicolumn{5}{|l|}{ 10-Aurlatian } \\
\hline \multicolumn{5}{|l|}{11 Marlpersa } \\
\hline \multicolumn{5}{|l|}{ 12-EI Segundp } \\
\hline \multicolumn{5}{|l|}{ 13-Dougbs (M日) } \\
\hline 14-Marina (Rodonda) & & & & - \\
\hline
\end{tabular}

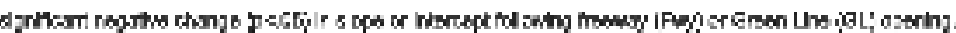

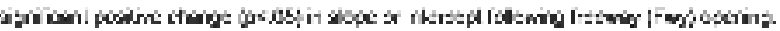

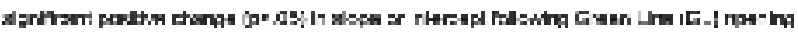
notitio no. hol yad h msdd.
} 


\section{Inner-city Stations}

After the opening of the Green Line, crime in the inner-city stations followed the declining trends witnessed throughout Los Angeles County (Figure 3). However, for four inner-city stations (\#6, \#7, \#8, and \#10) the decrease in nonauto related Type 1 crime was less than what would be expected based on the larger area trends (Table 3). These four stations were in jurisdictions with significantly higher crime rates than the county as a whole (Table 1). They tended, however, to have lower numbers of crimes than other stations in similar areas (see bar charts in Figure 4 which compare average crime levels in station neighborhoods ${ }^{9}$ ). For example, the neighborhoods around stations \#6 and \#7 had lower numbers of $\mathrm{cr}$ imes than stations \#4 and \#5.

The four inner-city stations that witnessed a significant increase in slope in nonautorelated Type 1 crime had different land uses. Stations \#6 and \#7 were primarily in residential neighborhoods with similar population density and demographic characteristics. The neighborhood around station \#8 in the City of Hawthorne had a low population density and primarily industrial land uses. Families that lived in this station neighborhood were mostly middle-income homeowners. Station \#10, which is close to the Los Angeles airport, was surrounded by vacant lots and parking lots with some industrial and office buildings.

Two inner-city station neighborhoods (\#6 and \#8) also witnessed a significant increase in slope for the post Green Line Type 2 crime trend. In particular, the neighborhood of Harbor Station (\#6) saw an absolute increase in Type 2 crime following the station opening.

\section{The Eastern Suburbs}

Crime data for the suburban City of Downey was only available from late 1993 so it was difficult to compare pre- and post- 1-105 Freeway crime trends. Nonautorelated Type 1 crime peaked for the City as a whole shortly after the Green Line opened and has been declining since then (Figure 5 ). In contras $t$, nonauto-related crime in the neighborhood of station \#2 has remained relatively stable at about 25 crimes per quarter, while Type 2 crime has increased, indicating that the introduction of the Green Line may have had some negative influence on station neighborhood crime rates (Table 3 ). 
Figure 4. Average Quarterly Crime Rate in Station Neighborhoods
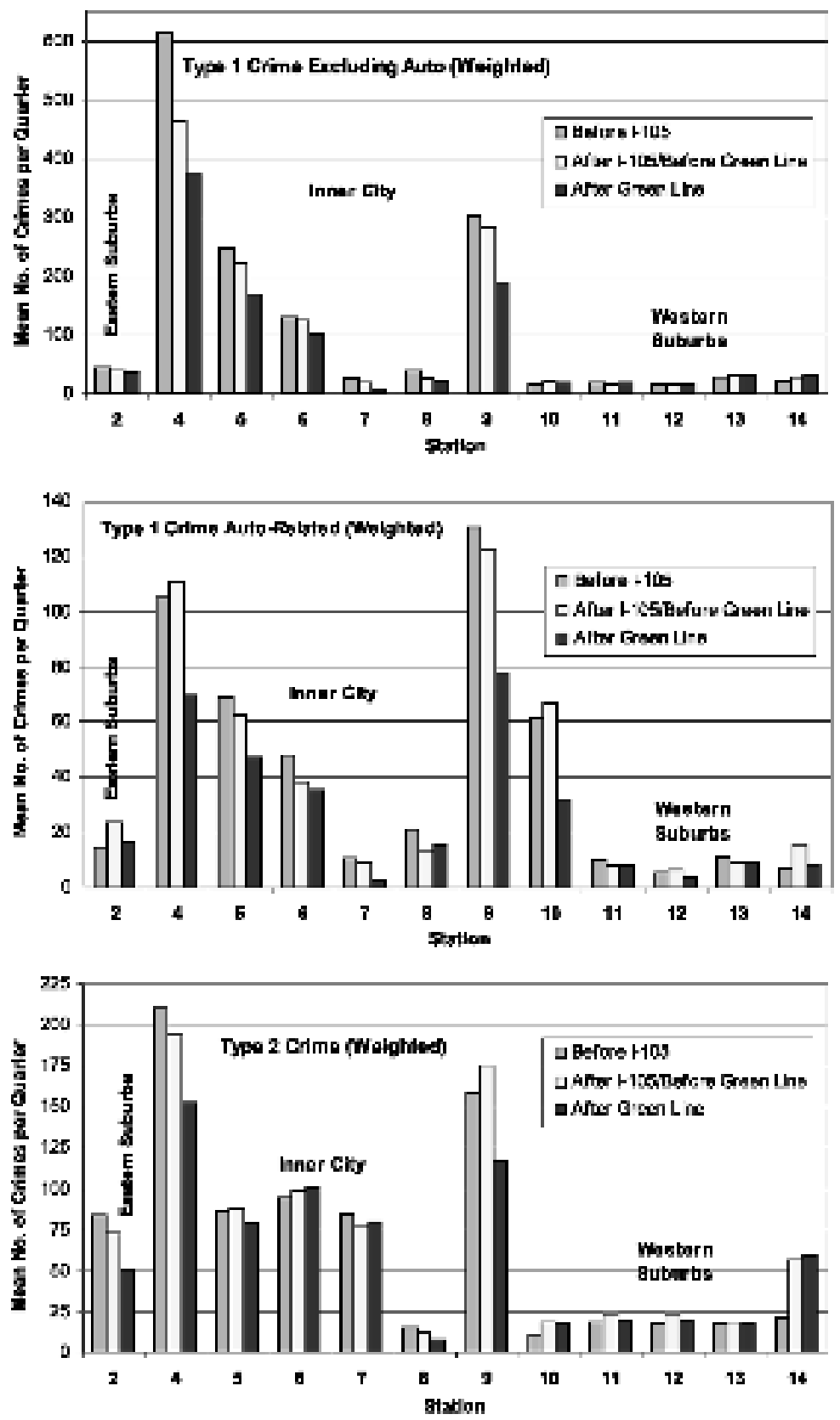


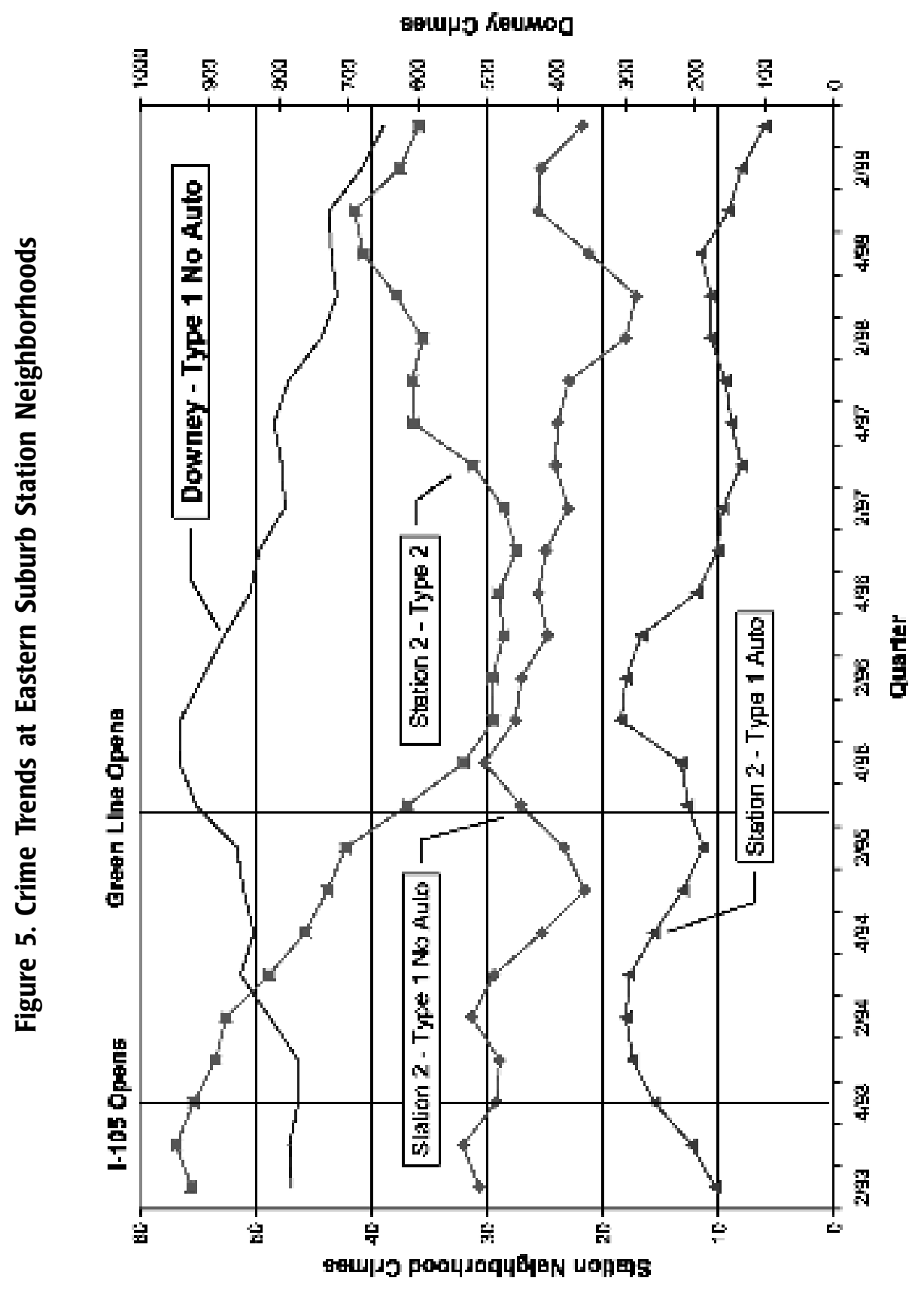




\section{The Western Suburbs}

We gave particular emphasis in documenting and analyzing shifts in crime trends at the western end of the line to test the assumption that an inner-city line brings crime to the suburbs. Significantly, we did not observe any increase in crime trends in the suburban stations at the west end of the line. In fact, in station \#14 in Redondo Beach, we witnessed a statistically significant decrease in crime in the station neighborhood after the line's opening (Table 3, Figure 6). Comparing station neighborhood crime to the countywide crime trends, we a gain did not see significant changes in the western suburban stations, with the only exception of an increase in auto-related crime in station \#13 (Table 4).

More specifically, the City of El Segundo, which is at the western end of the I-105 Freeway, has relatively low levels of crime. Type 1 crime, which increased in the period after the freeway opened, has been decreasing since the opening of the Green Line (about a 50\% decrease). Auto-related Type 1 crime has also been cut in half. The two station neighborhoods in El Segundo (\#11 and \#12) had few crimes; however, auto-related crime has been increasing in recent years. The regression model for station \#11 shows a significant post-Green Line increase in slope for auto-related Type 1 crime after controlling for local trends (i.e., trends in the City of El Segundo). However, when numbers of crimes are small (in this case autorelated Type 1 crime hovers between 5 and 10 crimes per quarter), a difference of just a few crimes can make it look as if there is a significant change in trend.

Station \#13 is located at the boundary of El Segundo and Manhat tan Beach in an area of relatively new (since early 1990s) upscale retail and commercial development. ${ }^{10}$ While Type 1 crime has been decreasing in the adjacent municipalities since 1993, we see a different picture in the area immediately surrounding station \#13, where such crime has been on an upward trend since the ear ly 1990s. However, there has been no significant change in this trend (i.e., increase in slope) with the opening of the Green Line (Figure 6). Rather, the increase in crime is most likely attributable to new developments since the early 1990s, such as office buildings, restaurants, movie theaters, and specialty stores that have att racted many visitors to the area. Station \#14, which is on the boundary of Redondo B each and southern Hawthorne, is the western terminus of the Green Line. As with station \#13, there was an increasing trend in Type 1 crimes in the $1 / 2$-mile around this station although this has decreased since the opening of the Green Line (the regression models show a significant negative change in slope) (Figure 6). There was more Type 2 crime in the area around station \#14 (about three times the level as at 


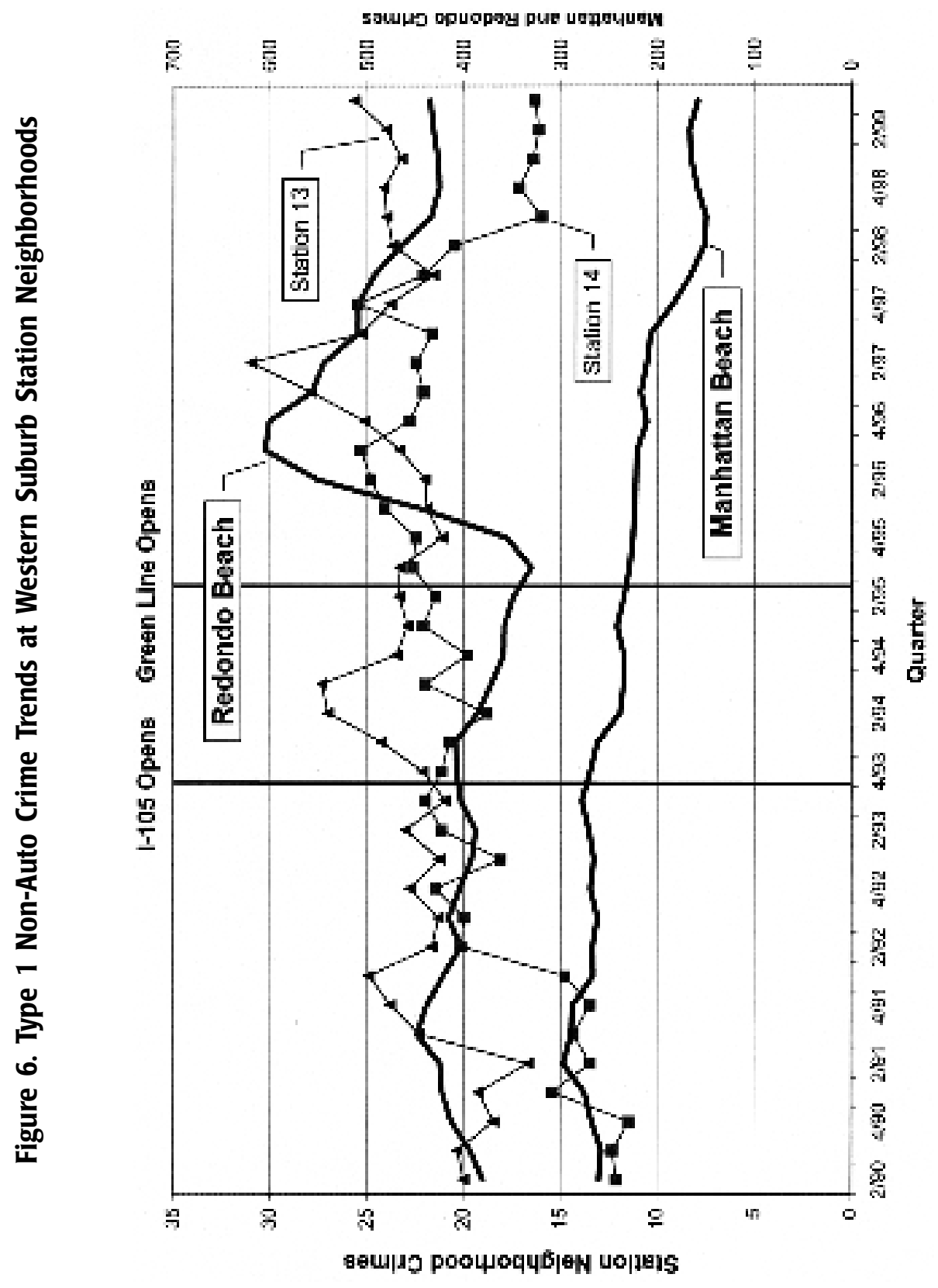


station \#13). While there was considerable fluctuation in the Type 2 crime trend it seemed to be gradually increasing. Particular land uses around station \#14, such as a continuation high school and a large discount retail shopping area, may be contributing to crime here.

\section{Hot Spot Analysis}

Crime specialists often argue that a localized decrease in crime may be elusive, as crime may be dislocated to neighboring sites in response to cer tain changes (e.g., more policing, new land uses, etc.). Therefore, in this part of the study, GIS and spatial analysis techniques were employed to examine changes in the spatial distribution of crimes in the communities served by the Green Line. Geocoded crime data was converted into crime-density grid maps (using ArcView Spatial Analyst) to identify and map hot spots of crime (concentrations of incidents). Analysis of these maps was followed by observational studies of the areas identified as hot spots of crime.

Maps showing average crime density (hot spots of crime) for the periods before and after $^{11}$ the opening of the Green Line can be seen in Figures 7 and 8. The maps in Figure 9 show the differences in crime concentrations betwee $n$ the two time periods. The upper map in Figure 9 shows hot spots of crime increase, where the lower map indicates areas where crime has decreased.

Figures 7 and 8 show high concentrations of both Type 1 and Type 2 crimes in the LA Central area before and after the introduction of the Green Line, although a significant decrease in crime density can be noticed (Figure 9). Our fieldwork showed that the few crime-density increases or shifts in density in the LA Central area took place in public housing developments.

Crime in Hawthorne was primarily concentrated along the commercial corridor of Hawthorne Boulevard (Figure 10), which runs south from station \#9, as well as in the southeast corner of the City, an area quite far from the Green Line. Both these areas have seen a decrease in crime density since the ope ning of the Green Line. Only one new hot spot has emerged in the neighborhood jus t south of the Green Line between stations \#8 and \#9 (Figure 9), in a resident ial area with singlefamily, detached dwelling units of varying condition (many with bars on the windows and doors as shown in the photo in Figure 11). 


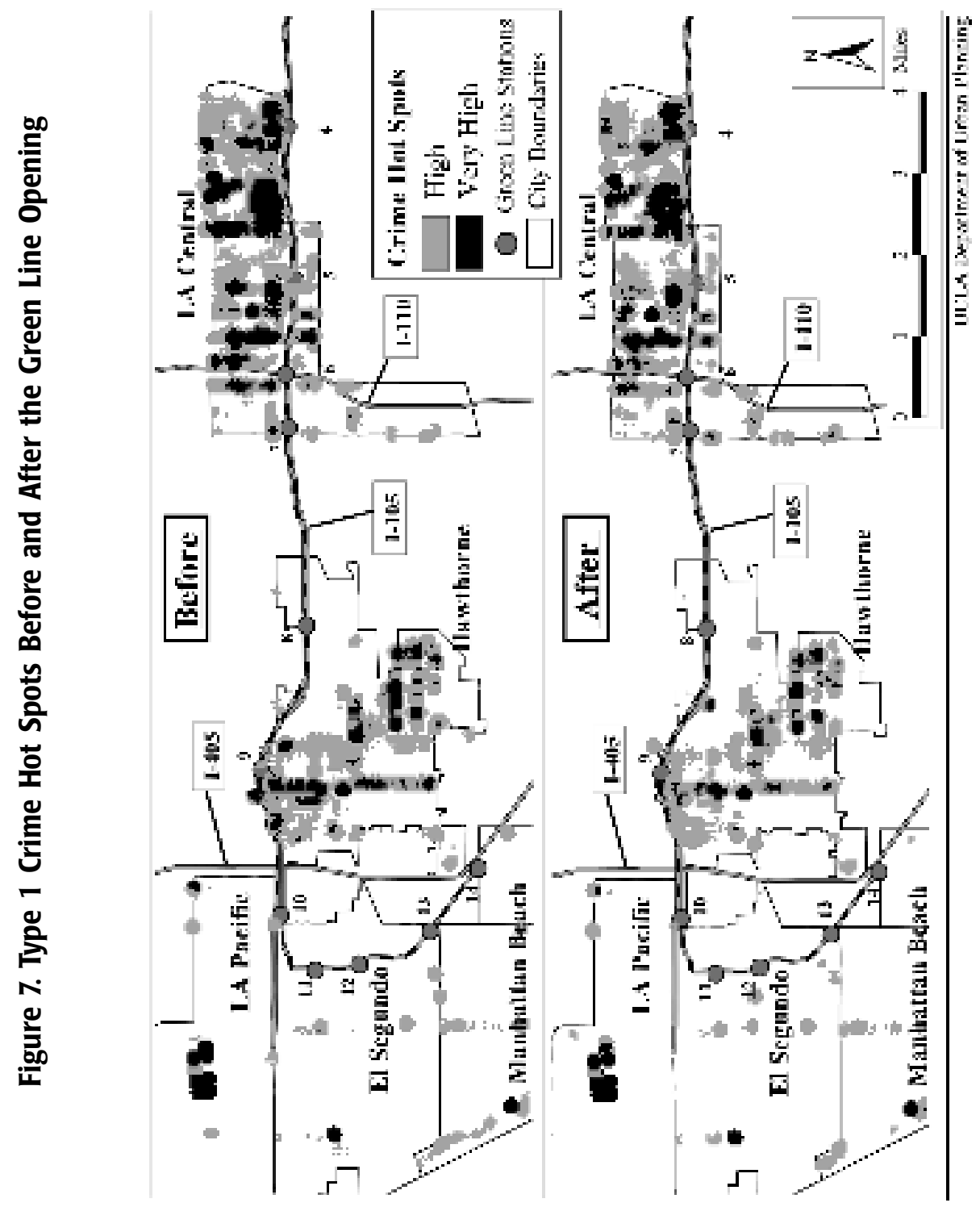




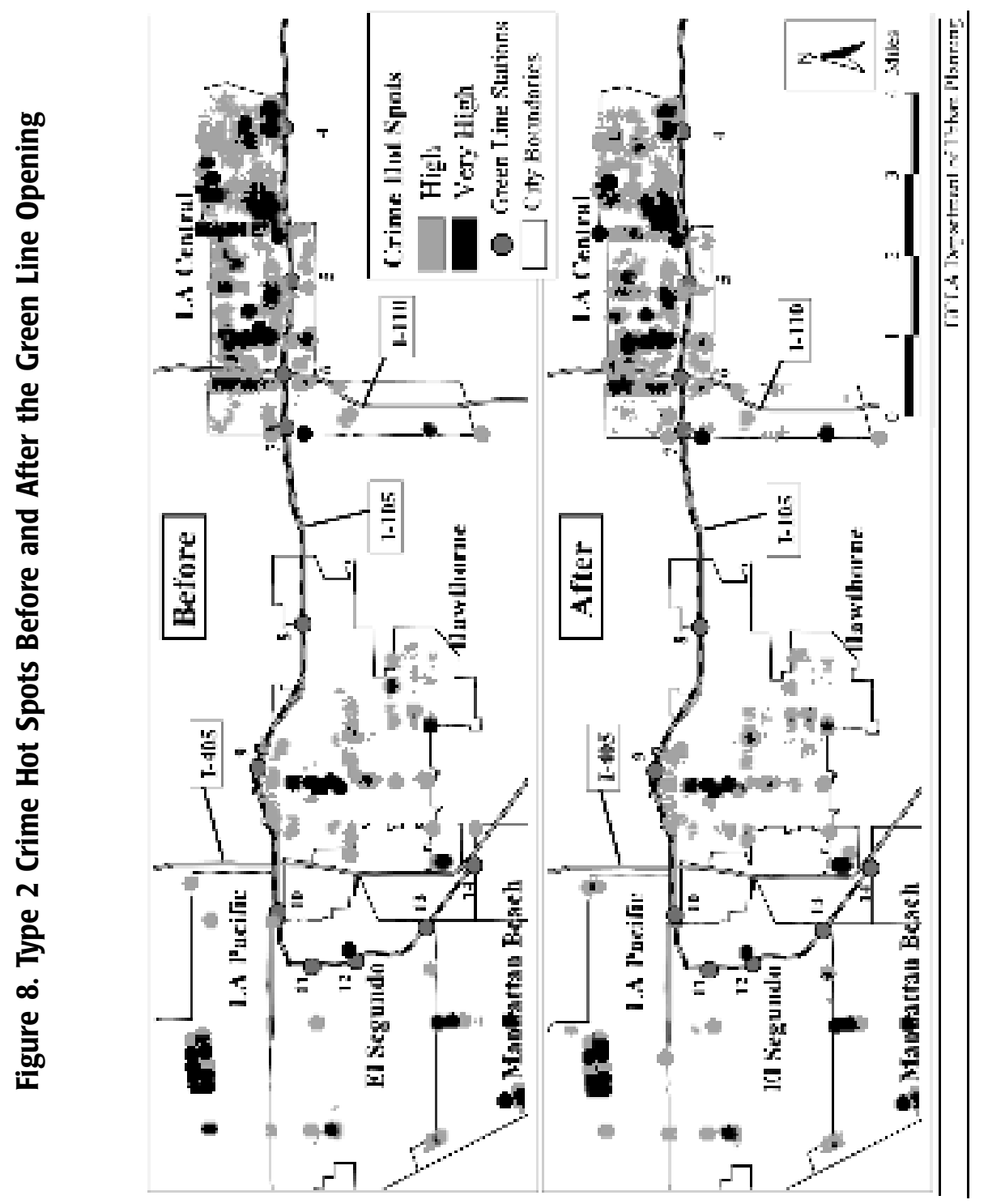




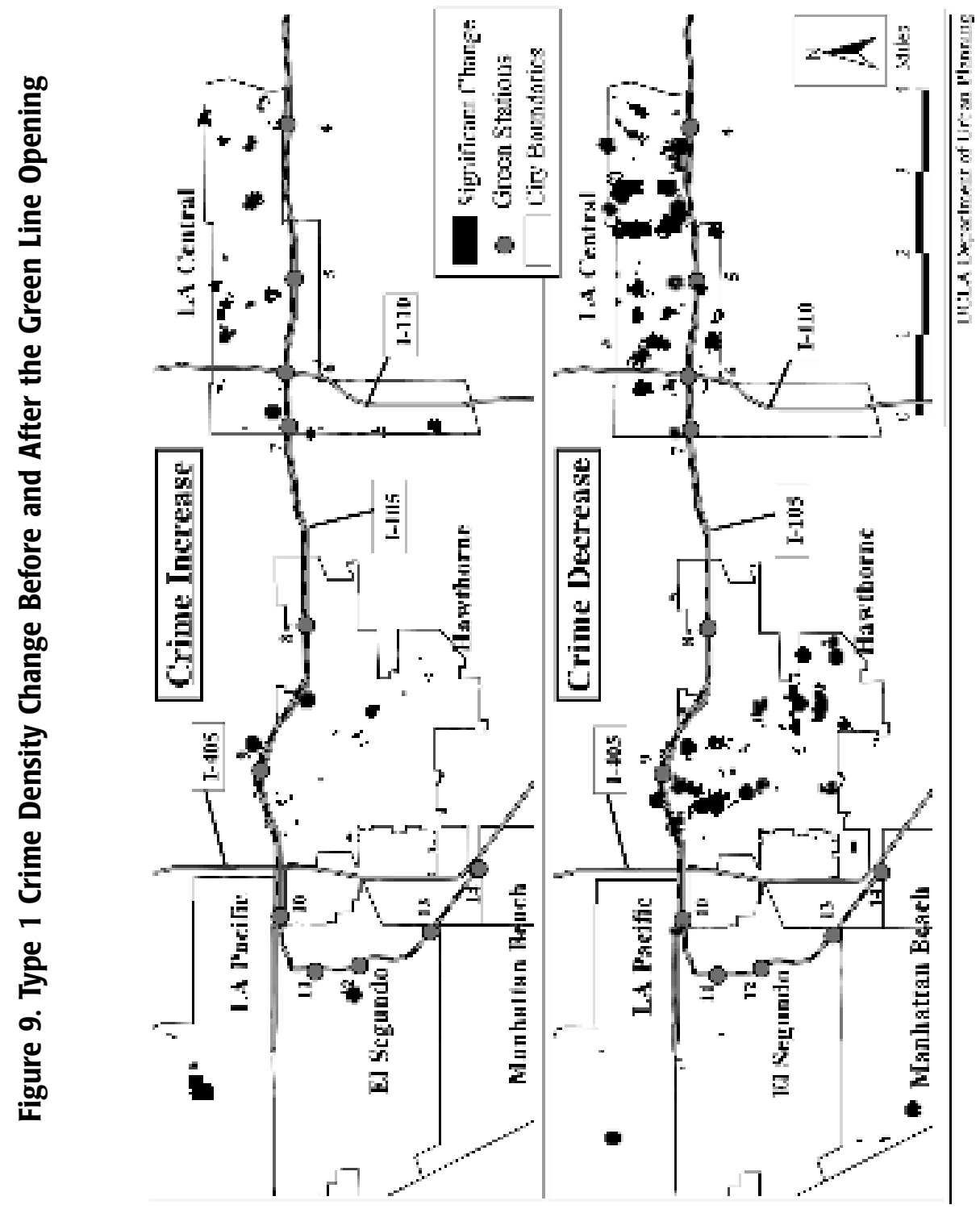


Figure 10. Howthorne Blvd., South of Station \#9

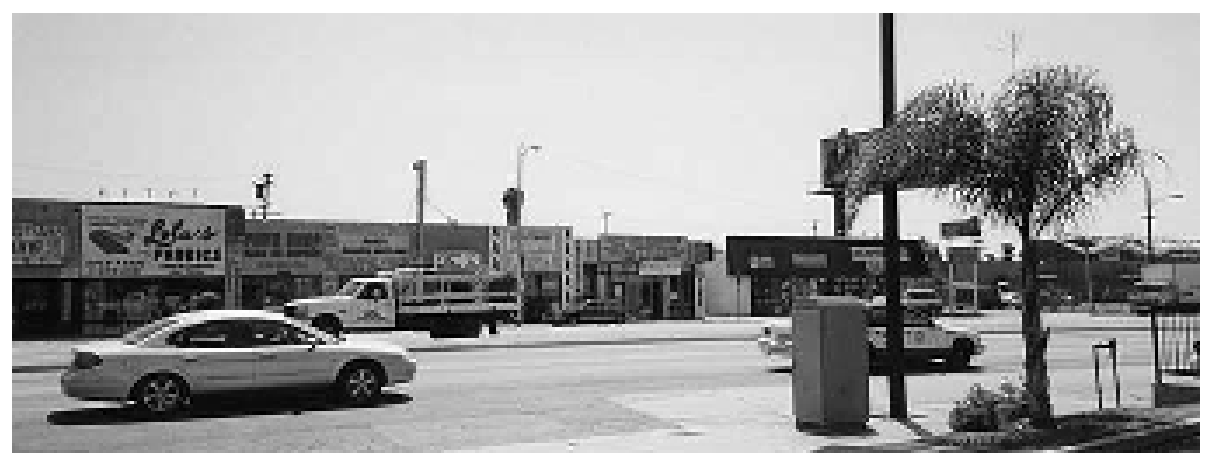

Figure 11. Single Family Neighborhood with Increased Crime

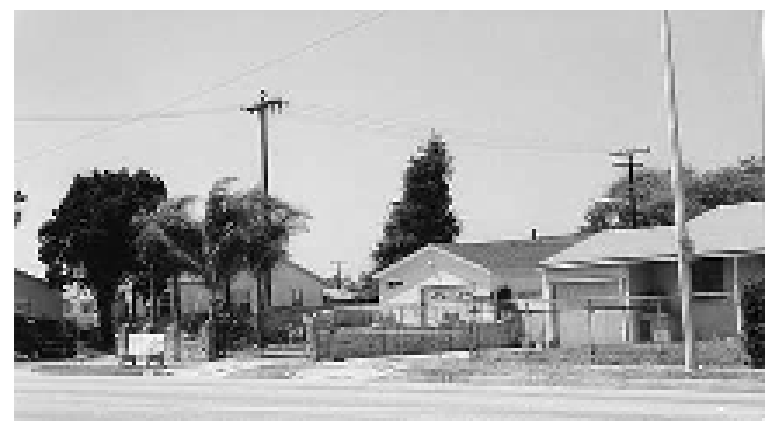

There were no hot spots of serious (Type 1) crime and only a few hot spots of Type 2 crime in the western suburbs. There has been a slightly highe $r$ concentration of Type 1 crime near station \#12 in El Segundo since the Green Line opening but this is likely due to the increased development in the area. Overall, the before and after pictures do not show any significant changes in the concentration of crime. 


\section{Conclusions}

At the end of the study, we find no evidence that this transit line has opened up new and outlying territories for exploitation by potential criminals. Overall, most station neighborhoods have either experienced no change or have witnessed a reduction in crime after the introduction of the Green Line. Transit has certainly not brought more crime to the affluent suburban areas, which have continued to enjoy relatively higher levels of safety and prosperity than the County average. Some crime increase was witnessed in the inner city, where limited spillover effects of crime from more high crime to less crime-ridden areas were observed. However, major shifts and dislocation of crime have not occurred within the municipalities that surround the Green Line. We were also unable to notice a relationship between hot spots of crime and proximity to a transit station. Ra ther the existence of hot spots could be better explained by the presence of certain land uses (e.g., concentration of retail along a busy commercial street, existen ce of a high school, or a public housing development).

This study is limited by the fact that it only examined one light rail line. Also the findings cannot prove or disprove the distance-decay theory, as we were not aware of the points of origin of the different criminals who committe d crimes in station neighborhoods. However, it seems clear that criminals have not used the Green Line to access potential targets miles away. The journey to crime has not become easier because of the Green Line.

\section{Acknowledgments}

This study has been supported by grants from the John Randolph and Dora Haynes Foundation and the California Department of Transportation (through the University of California Transportation Center).

\section{Endnotes}

${ }^{1}$ Rhodes and Conly (1981) found that criminals tend to be primar ily attracted to commercial and transitional areas, followed by industrial areas. Residential areas are considered less attractive. Multiple-family housing tends to attract more crime than single-family housing.

${ }^{2}$ Comparisons of high- and low-crime neighborhoods have shown that area accessibility is associated with high crime (Eck and Weisburd 1995). 
${ }^{3}$ The Green Line crosses 13 political jurisdictions: Norwalk, Downey, Paramount, South Gate, Lynwood, City of Los Angeles, Inglewood, Hawthorne, El Segundo, Manhattan Beach, Redondo Beach, Lawndale, and unincorporated ar eas of Los Angeles County.

${ }^{4}$ For classification purposes the Federal Bureau of Investigation has classified crime into two major categories: Type 1 crime (criminal homicide, forcible rape, robbery, aggravated assault, larceny theft, burglary, grand auto theft, and arson), and Type 2 crime (crime of less serious nature against people and their property, such as petty theft, disorderly conduct, vagrancy, non-aggravated assaults, drug violation, etc.). For purposes of this study, we further divided Type 1 crime into nonautorelated crimes versus auto-related crimes. Crime classifications were not consistent across the various jurisdictions from which crime data was collected making it difficult to compare crime statistics across jurisdictions.

${ }^{5}$ Crimes used in this study do not include crimes at the station s or the station parking lots, which were reported in Loukaitou-Sideris et al. (2002). We are looking rather at changes in crime levels in the neighborhoods surrounding the stations and shifts in crime locations in the larger jurisdictions around the Green Line.

${ }^{6}$ Historically, crime trends have followed economic/employment trends (Koch Crime Institute 1998). The study reported in this article coinc ided with a period of economic growth and a declining crime trend nationwide.

${ }^{7}$ Variables associated with the opening of the I-105 Freeway were not considered in the models for stations \#2, \#13, and \#14. Sufficient data wa s not available to develop a prefreeway trend for station \#2. Stations \#13 and \#14 are not located in the vicinity of the $1-105$.

${ }^{8}$ Type 2 crime trend data was not available at the county level.

${ }^{9}$ Crime data could not be collected for the full $1 / 2$-mile radius s urrounding some of the stations due to differences in political jurisdictions. Crime data collected for each station neighborhood was weighted to account for area differences for comparison purposes in the bar charts.

${ }^{10}$ Since this station as well as station \#14 are not particularly close to the 1-105 Freeway and are located within a few of blocks of the older 405 Freeway, the 
Journal of Public Transportation, Vol. 6, No. 3, 2003

regression models used for both stations do not include dummy variables for the 1-105 Freeway.

${ }^{11}$ Crime-density maps are based on data for seven quarters before and seven quarters after the opening of the Green Line. 


\section{References}

AEGIS Systems, Inc. 1991. Green line security analysis appendices. Prepared for Transportation Consultants of Southern California, April.

Block, R. and C. Block. 2000. The Bronx and Chicago: Street rob bery in the environs of rapid transit stations. In J. Mollenkopf, ed., Analyzing Crime Patterns: Frontiers in Practice. London: Sage.

Block, R, and S. Davis. 1996. The environs of rapid transit sta tions: A focus for street crime or just another risky place? In R. Clarke, ed., Preventing mass transit crime. Monsey, NY: Criminal Justice Press.

Boggs, S. 1966. Urban crime problems. American Sociological Review 30 (December): 899-908.

Brantingham, P., and P. Brantingham. 1981. Environmental criminology, Beverly Hills: Sage Publications.

Brantingham, P., and P. Brantingham. 1984. Patterns in crime. New York: Macmillan.

Brantingham, P., and Brantingham. 1991. How public transit feeds private crime: Notes on the Vancouver 'Skytrain' experience. Security 3 (2): 91-95.

Brantingham, P., and P. Brantingham. 1995. Criminality and place: Crime generators and crime attractors. European Journal of Criminal Policy and Research 3: $5-26$.

Capone, D., and W. Nichols. 1976. Urban structure and criminal mobility. American Behavioral Scientist 20 (2): 199-213.

Eck, J. and D. Weisburd. 1995. Crime and place. Monsey, NY: Willow Tree Press.

Felson, M., D. Dickman, D. Glenn, L. Kelly, G. Lambard, L. Maher, L. Nelson-Green, C. Ortega, T. Preiser, A. Rajedran, T. Ross, L. Tous, and J. Veil. 1990. Preventing crime at Newark subway stations. Security Journal 1 (3): 137-142.

Koch Crime Institute. 1998. The falling crime rate. Koch Crime Institute White Paper Report.

Lind, A. W. 1930. Some ecological patterns of community disorganization in Honolulu. American Journal of Sociology 36 (2): 206-220.

Loukaitou-Sideris, A., R. Liggett, and H. Iseki. 2002. The geog raphy of transit crime: Documentation and evaluation of crime incidence on and around $G$ reen Line 
Stations in Los Angeles. Journal of Planning Education and Research 22 (2): 135-151.

Loukaitou-Sideris, A., and T. Banerjee. 2000. Form flows transit? The Blue Line Corridor's development potential. University of California Transportation Paper. Berkeley: University of California Transportation Center, Working Paper \#259.

Myhre, M., and F. Rosso. 1996. Designing for security in meteor: A projected new metro line in Paris. In R. Clarke, ed. Preventing Mass Transit Crime, Monsey, NY: Criminal Justice Press.

Plano, S.L. 1993. Transit-generated crime: Perception vs. reality: A Sociogeographic study of neighborhoods adjacent to Section B of Baltimore Metro. Transportation Research Record 1402: 59-62.

Poister, T. 1996. Transit-related crime in suburban areas. Journal of Urban Affairs 18 (1): 63-76.

Pyle, G. F. 1976. Spatial and temporal aspects of crime in Cleveland, Ohio. American Behavioral Scientist 20 (2): 175-196.

Rhodes, W. M. and C. Conly. 1981. Crime and mobility: An empirical study. In Brantingham, P. and Brantingham, P., eds. Environmental criminology. Beverly Hills: Sage Publications.

Ross, C. and J. Stein. 1985. Business and residential perceptions of a proposed rail station: Implications for transit planning. Transportation Quarterly 39 (4): 483-493.

Shellow, R., J. Romualdi, and E. Bartel. 1974. Crime in rapid transit systems: An analysis and a recommended security and surveillance system. Transportation Research Record 487: 1-12.

Smith, G. 1991. Statistical reasoning. Needham Heights, MA: Allyn and Bacon.

Van Koppen, P., and J. W. De Keijer. 1997. Desisting distance decay: On the aggregation of individual crime trips. Criminology 35 (3): 505-515.

White, R. C. 1932. The relation of felonies to environmental fa ctors in Indianapolis. Social Forces 10 (4): 498-509. 


\section{About the Authors}

RoBin LigGetr (rliggett@ucla.edu) holds a joint professorship between the Departments of Architecture and Urban Planning at UCLA where she teac hes courses in quantitative methods and computer applications. Her research emphasis is on the development of interactive computer graphic aides for design and decision making. Her recent projects include software tools for real-time 3-D visual simulation of urban environments and statistical models for investiga ting the effects of the built environment on transit crime.

AnAstasia Loukaitou-Sideris (sideris@ucla.edu) is a professor in the Department of Urban Planning at the UCLA School of Public Policy and Social Research. She specializes in urban design, physical and land-use planning. Sh e has written articles on transit safety, transit-oriented design, downtown development, inner-city revitalization, cultural determinants of design, and open space design. She is the coauthor of Urban Design Downtown: Poetics and Politics of Form (University of California Press: 1998).

HIRoyukı IseKı (hiseki@ucla.edu) is a Ph.D. candidate in the Department of Urban Planning at the UCLA School of Public Policy and Social Researc $h$ and a graduate research assistant at the UCLA Institute of Transportation Studies. His research interests are in transportation planning, transportation policy analysis, and application of GIS to planning. He has coauthored articles on transit cost allocation model, transit equity, transit safety, and a survey on agencies' practice to increase ridership. 